\title{
Theoretical Study of Shliomis Model Based Magnetic Squeeze Film in Rough Curved Annular Plates With Assorted Porous Structures
}

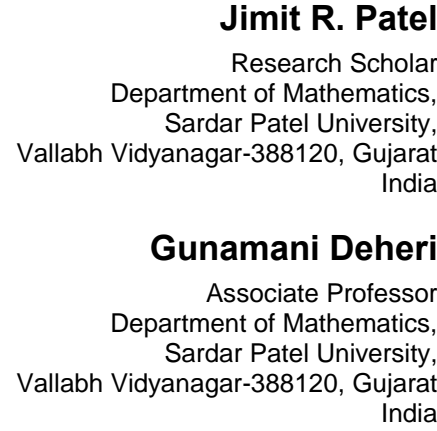

Jimit R. Pate artment of Mathematics, Sardar Patel University India

\section{INTRODUCTION}

In the field of engineering and technology, annular bearing are often designed to bear the transverse loads. The study of performance characteristics of annular bearings with different shape and different lubricants has been done from time to time by the researchers. [1] studied the effect of ferrofluid on the curved squeeze film between two annular plates, when the upper plate approached the lower one normally including the rotation of the magnetic particles and their magnetic moments. [2] analyzed the behaviour of a magnetic fluid based squeeze film between rotating transversely rough porous annular plates incorporating elastic deformation. [3] examined the combined effect of couple stresses and surface roughness patterns on the squeeze film characteristics of curved annular plates.

The positive effect of magnetic fluid lubricant drew considerable attentions during the last two decades. Recently, many theoretical and experimental investigations were made using a ferrofluid as lubricant owing to its various advantages such as in seals, dampers, sensors, coating system and load speakers. On the other hand, [4] proposed a ferrofluid flow model in which the effect of rotation of magnetic particles, their magnetic moments and the volume concentration were included. [5] analyzed the effect of rotational inertia on the squeeze film load between porous annular curved

Received: December 2013, Accepted: January 2014

Correspondence to: Jimit R. Patel

Department of Mathematics,Sardar Patel University,

Vallabh Vidyanagar-388120,Gujarat, India

E-mail: patel.jimitphdmarch2013@gmail.com

doi:10.5937/fmet1401056P

(C) Faculty of Mechanical Engineering, Belgrade. All rights reserved plates. It was found that the load carrying capacity decreased when the speed of rotation of the upper disk increased up to certain value. It was shown that the load carrying capacity could be enhanced without altering the speed of rotation by increasing the upper plate's curvature parameter. [6] analyzed that the magnetic energy was partially transformed into the angular momentum of the magnetic particles which in turn, was converted into a hydrodynamic motion of the fluid. [7] dealt with the effect of fluid inertia in magneto hydrodynamic annular squeeze films. It was concluded that the inertia correction factor in the magneto hydrodynamic load carrying capacity was more pronounced with large Hartmann numbers. [8] theoretically presented the effect of ferrofluid on the dynamic characteristics of curved slider bearings using Shliomis model. [9] discussed the influence of fluid inertia forces on the ferrofluid squeeze film between a sphere and a plate in the presence of external magnetic fields on the ground of the ferrohydrodynamic model proposed from by [4]. All these above studies established that the volume concentration and the intensity of magnetic field provided an increase in the load carrying capacity and the time of approach due to the Shliomis model based magnetic fluid lubrication.

By now, it is well established that porous materials are used in a wide variety of applications which includes catalyses, chemical separation and tissue engineering. Porous structures are very important in biomedical applications where there are strict limits on the amount of residual organic solvent that may remain in the materials; this provides a strong driving force to seek non- toxic solvent alternatives. Of course, one 
needs to remember that surface modification or templating of nano porous material presents some special problem because organic solvents are often too viscous to fill such small pores. In view of their wide range of applications, theoretical studies have been conducted by [10-11]. Recently, [12] discussed the effect of various porous structures on the performance of a Shliomis model based ferrofluid lubrication of a squeeze film in rotating rough porous curved circular plates. It was found that the adverse effect of transverse roughness could be overcome by the positive effect of ferrofluid lubrication in the case of negatively skewed roughness when Kozeny- Carman's model is deployed by suitably choosing curvature parameters and rotational inertia.

In most of the investigations, it has been considered that the bearing surfaces are smooth. This is an unrealistic assumption for the bearing operating with small film thickness. In the last decade, a considerable amount of tribological research has been conducted to study the effect of surface roughness on hydrodynamic lubrication. This is mainly because of the fact that all solid surfaces are rough to some extent and generally the height of roughness asperities is of the same order of magnitude as the mean separation between lubricated contacts. In literature, several investigations such as [13-18] accounting for surface roughness effect have been proposed in order to seek a more realistic representation of bearing surfaces. [19] analyzed the effect of magneto-hydrodynamic squeeze film characteristics between curved annular plates. On the basis of the Christenson and Tonder's stochastic model of roughness, the discussion carried out by [2023] reported that the negatively skewed roughness turns in better performance. All these above studies established that increasing values of porosity caused reduced load carrying capacity and friction. The combination of magnetization and negatively skewed roughness reduced the friction. Moreover, porosity played a seminal role in improving the overall performance of a bearing system by choosing a suitable range of roughness parameters with proper selection of rotation ratio. Lastly, [24] presented the performance of a ferrofluid based squeeze film in rotating rough curved circular plates resorting to Shliomis model. It was concluded that the adverse effect of roughness could be reduced considerably at least in the case of negatively skewed roughness with a suitable choice of curvature parameters.

The aim of this paper is to theoretically analyze the performance of Shliomis model based ferrofluid squeeze film in curved rough annular plates with a comparison between the porous structure of KozenyCarman and capillary fissures model of Irmay.

\section{ANALYSIS}

The geometry of the bearing system which consists of annular plates is displayed in Figure 1. The bearing consists of two annular plates each of inside radius $b$ and outside radius $a(a>b)$. Surfaces of both disks are considered to be transversely rough. The upper plate moves towards the lower plate normally with uniform velocity $\dot{h_{0}}=\mathrm{dh}_{0} / \mathrm{dt}$.

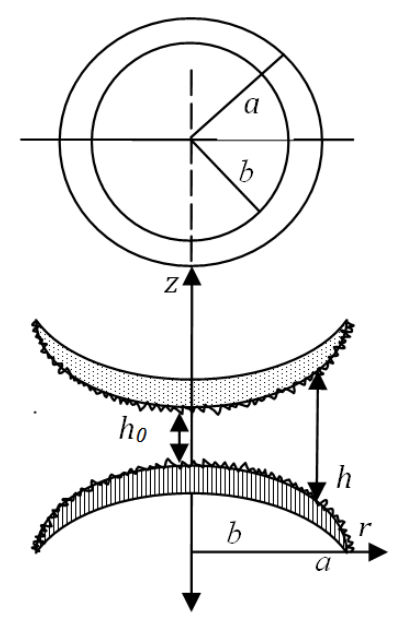

Figure 1. Configuration of the bearing system

In view of the discussions concerning the stochastic modeling of transverse roughness mooted by [14-16], the film thickness $\mathrm{h}(\mathrm{x})$ is assumed to be,

$$
h(x)=\bar{h}(x)+h_{s}
$$

where $\bar{h}(x)$ denotes the mean film thickness and $h_{s}$ is the deviation from the mean film thickness characterizing the random roughness of the bearing surfaces. The deviation $h_{s}$ is obtained by a generalized probability density function

$$
f\left(h_{s}\right)=\left\{\begin{array}{c}
\frac{35}{32 c}\left(1-\frac{h_{s}^{2}}{c^{2}}\right)^{3},-c \leq h_{s} \leq c \\
o, \text { otherwise }
\end{array}\right.
$$

where $\mathrm{c}$ is the maximum deviation from the mean film thickness. The mean $\alpha$, the standard deviation $\sigma$ and the parameter $\varepsilon$, which is the measure of symmetry of the random variable $h_{s}$, are defined by the relationships:

$$
\alpha=E\left(h_{s}\right), \sigma^{2}=E\left[\left(h_{s}-\alpha\right)^{2}\right], \varepsilon=E\left[\left(h_{s}-\alpha\right)^{3}\right]
$$

where $E$ denotes the expected value defined by

$$
E(R)=\int_{-c}^{c} R f\left(h_{s}\right) d s
$$

The details can be seen from [14-16].

It is assumed that the upper disk lying along the surface determined by the relation

$$
z_{u}=h_{0} \exp \left(-\beta r^{2}\right) ; a \leq r \leq b
$$

approaches with normal velocity $\left(\dot{h}_{0}\right)^{\cdot}$ to the lower plate, lying along the surface given by

$$
z_{l}=h_{0}\left[\exp \left(-\gamma r^{2}\right)-1\right] ; a \leq r \leq b
$$

where $h_{0}$ is the central distance between the plates, $\beta$ and $\gamma$ are the curvature parameters of the corresponding 
plates. The film thickness $h(r)$ then, is defined by $[22,25]$

$$
h(r)=h_{0}\left[\exp \left(-\beta r^{2}\right)-\exp \left(-\gamma r^{2}\right)+1\right] ; a \leq r \leq b
$$

In fact, magnetic fluids (or ferrofluids) are stable colloidal suspensions of very fine magnetic particles in a viscous fluid (carrier liquid). These types of fluids can be positioned, confined or controlled at desired places under the application of an external magnetic field. The external magnetic field further introduces an increase in effective viscosity of the ferro solution. This indeed has resulted in increased application of magnetic fluids as lubricants in bearing systems. It is pertinent to note that most of the studies deal with the model of NeuringerRosensweig which assumes that the magnetization vector is parallel to the applied magnetic field. This restriction is relaxed in the model of Shliomis which takes into account the particle rotation also. [4] suggested that magnetic particles of a magnetic fluid could relax in two ways when the applied magnetic field changed. One was by the rotation of magnetic particles in the fluid and the other one by rotation of the magnetic moment with in the particles. Brownian relaxation time parameter $\tau_{B}$ gives particle rotation while the relaxation time parameter $\tau_{S}$ describes the intrinsic rotational process. Assuming steady flow, neglecting inertial and second derivatives of $\bar{S}$, the equations governing the flow become,

$$
\begin{aligned}
-\nabla_{p}+\eta \nabla^{2} \bar{q} & +\mu_{0}(\bar{M} \cdot \nabla) \bar{H}+\frac{1}{2 \tau_{S}} \nabla \times(\bar{S}-I \bar{\Omega})=0 \\
\bar{S} & =I \bar{\Omega}+\mu_{0} \tau_{S}(\bar{M} \times \bar{H}) \\
\bar{M} & =M_{0} \frac{\bar{H}}{H}+\frac{\tau_{B}}{I}(\bar{S} \times \bar{M})
\end{aligned}
$$

where $\bar{S}$ is the internal angular momentum, I is the sum of moment of inertia of the particles per unit volume, $\bar{\Omega}=\frac{1}{2} \nabla \times \bar{q}$, together with

$$
\nabla \cdot \bar{q}=0, \nabla \times \bar{H}=0, \nabla \cdot(\bar{H}+\bar{M})=0
$$

[25], $\bar{q}$ is the fluid viscosity in the film region, $\bar{H}$ is external magnetic field, $\bar{M}$ is magnetization vector, $\bar{\mu}$ is magnetic susceptibility of the magnetic field, $\mathrm{p}$ is the film pressure, $\eta$ is the fluid viscosity, $\mu_{0}$ is the permeability of the free space and $M_{0}$ is the equilibrium magnetization. By using equation (3), in equation (2) and (4), one finds that,

$$
-\nabla_{p}+\eta \nabla^{2} \bar{q}+\mu_{0}(\bar{M} . \nabla) \bar{H}+\frac{1}{2} \mu_{0} \nabla \times(\bar{M} \times \bar{H})=0(5)
$$

and

$$
\bar{M}=M_{0} \frac{\bar{H}}{H}+\tau_{B}(\bar{\Omega} \times \bar{M})-\frac{\mu_{0} \tau_{B} \tau_{S}}{I} \bar{M} \times(\bar{M} \times \bar{H})(6)
$$

At this stage, one needs to remember that Langevin's parameter $\xi$ is a measure of the dimensionless field strength. For a strong magnetic field $\xi>1$. In this case $\tau_{S}$ can't be neglected. Then equation (6) takes the form as,

$$
\bar{M}=\frac{M_{0}}{H}(\bar{H}+\bar{\tau}(\bar{\Omega} \times \bar{H}))
$$

where

$$
\bar{\tau}=\frac{\tau_{B}}{1+\frac{\mu_{0} \tau_{B} \tau_{S}}{I} M_{0} H}
$$

For a suspension of spherical particles $I / \tau_{S}=6 \eta \phi$ and $\tau_{B}=3 \eta V /\left(k_{B} T\right)$, where $\phi=n V$ is the volume concentration of the particles, $\mathrm{k}_{\mathrm{B}}$ is the Boltzmann constant, $n$ is the number of particles per unit volume and $T$ is the temperature, one can obtain $\bar{\tau}$ as

$$
\bar{\tau}=\frac{6 \eta \phi}{n k_{B} T(1+\xi \operatorname{coth} \xi)}
$$

By taking $M_{0}=\eta \mu(\operatorname{coth} \xi-1 / \xi)$ and $=k_{B} T \xi / \mu_{0} \mu, \mu$ being magnetic moments of a particle, as in [4], (9).

In an axially symmetric flow under a uniform magnetic field $\bar{H}=\left(0,0, H_{0}\right)$ with radial velocity component, (5) to (7) yield

$$
\frac{\partial^{2} u}{\partial z^{2}}=\frac{1}{\eta\left(1+\frac{\mu_{0} M_{0} H_{0} \bar{\tau}}{4 \eta}\right)} \frac{d p}{d r}
$$

Using (8)-(10) one obtains

$$
\frac{\partial^{2} u}{\partial z^{2}}=\frac{1}{\eta(1+\tau)} \frac{d p}{d r}
$$

where

$$
\tau=\frac{3}{2} \phi \frac{\xi-\tanh \xi}{\xi+\tanh \xi}
$$

Solving (11) under the no-slip boundary conditions $u=0$ when $z=0, h$.

one gets

$$
u=\frac{z^{2}-h z}{2 \eta(1+\tau)} \frac{d p}{d r}
$$

Substituting in the integral form of continuity equation

$$
\frac{1}{r} \frac{d}{d r} \int_{0}^{h} r u d z+h_{0}
$$

yields,

$$
\frac{1}{r} \frac{d}{d r}\left(h^{3} r \frac{d p}{d r}\right)=12 \eta(1+\tau) \dot{h}_{0}
$$

Making use of Einstein formula $\eta=\eta_{0}(1+5 / 2 \Phi)$, where $\eta_{0}$ is the viscosity of the main liquid, Equation (13) reduces to 


$$
\frac{1}{r} \frac{d}{d r}\left(h^{3} r \frac{d p}{d r}\right)=12 \eta_{0}\left(1+\frac{5}{2} \phi\right)(1+\tau) \dot{h}_{0}
$$

For the stochastical averaging of this differential equation, a method has been proposed in [14-16]. Here attempt has been made to modify this method, which can certain simplifications yields, under the usual assumptions of hydro-magnetic lubrication [25-27] the modified Reynolds equation takes the form

$$
\begin{gathered}
\frac{1}{r} \frac{d}{d r}\left(\left(g(h)+12 \psi l_{1}\right) r \frac{d p}{d r}\right)= \\
\quad=12 \eta_{0}\left(1+\frac{5}{2} \phi\right)(1+\tau) h_{0}
\end{gathered}
$$

where

$$
g(h)=h^{3}+3 h^{2} \alpha+3\left(\sigma^{2}+\alpha^{2}\right) h+3 \sigma^{2} \alpha+\alpha^{3}+\varepsilon
$$

and $l_{l}$ is porous layer thickness and $\psi$ is permeability of porous region.

The following non dimensional quantities are introduced,

$$
\begin{gathered}
\bar{h}=\frac{h}{h_{0}}, R=\frac{r}{b}, P=-\frac{h_{0}^{3} p}{\eta_{0} b^{2} h_{0}}, B=\beta b^{2}, C=\gamma b^{2}, \\
\bar{\sigma}=\frac{\sigma}{h_{0}}, \bar{\alpha}=\frac{\alpha}{h_{0}}, \bar{\varepsilon}=\frac{\varepsilon}{h_{0}^{3}}, k=\frac{a}{b}, \bar{\psi}=\frac{D_{c}^{2} l_{1}}{h_{0}^{3}}, \\
\psi^{*}=\frac{D_{s}^{2} l_{1}}{h_{0}^{3}}, A=\frac{12 \bar{\psi} e^{3}}{J(1-e)^{2}}, \\
D=\frac{12 \psi^{*}\left(1-(1-e)^{\frac{1}{3}}\right)^{3}\left(1+(1-e)^{\frac{1}{3}}\right)}{I^{*}(1-e)}
\end{gathered}
$$

The associated boundary conditions are:

$$
P(1)=P(k)=0
$$

The two different porous structures are discussed below.

\subsection{A globular sphere model as displayed in Figure 2}

In this model, a porous material is filled by globular spherical particles, with a mean particle size $D_{c}$.

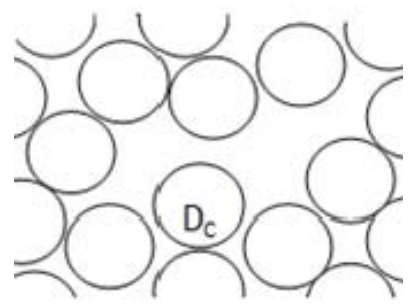

Figure 2. Configuration of a globular sphere model

The Kozeny-Carman equation is well known in fluid dynamics. Relatively better results for pressure drop are obtained when this model is applied to laminar flow. The hydraulic radius theory of Kozeny-Carman formulation resulted in the relationship $[10,28]$

$$
\psi=\frac{D_{c}^{2} e^{3}}{J(1-e)^{2}}
$$

where $e$ is the porosity parameter and $J$ is a parameter known to depend on the morphology of pores. From experimental investigation, usually 180 are set for the permeability structure presented by Kozeny-Carman. The Kozeny-Carman equation yields satisfactory results for media that consists of particles of approximately spherical shape and whose diameter fills with a narrow range.

Making use of the boundary conditions (17) and non dimensional quantities (16), one obtains the dimensionless pressure distribution for globular sphere model in a following form

$$
\begin{gathered}
P=-6\left(1+\frac{5}{2} \phi\right)(1+\tau) \int_{1}^{R} \frac{R}{g(\bar{h})+A} d R+ \\
+C_{1} \int_{1}^{R} \frac{d R}{R\{g(\bar{h})+A\}}
\end{gathered}
$$

where

$$
\begin{gathered}
C_{1}=6\left(1+\frac{5}{2} \phi\right)(1+\tau) \frac{\int_{1}^{k} \frac{R d R}{g(\bar{h})+A}}{\int_{1}^{k} \frac{d R}{R\{g(\bar{h})+A\}}} \\
g(\bar{h})=\bar{h}^{3}+3 \bar{h}^{2} \bar{\alpha}+3\left(\bar{\sigma}^{2}+\bar{\alpha}^{2}\right) \bar{h}+3 \bar{\sigma}^{2} \bar{\alpha}+\bar{\alpha}^{3}+\bar{\varepsilon}
\end{gathered}
$$

The non-dimensional load carrying capacity of the bearing system is obtained from

$$
W=-\frac{h_{0}^{3}}{2 \pi \eta b^{4} h_{0}} w=\int_{1}^{k} R P d R
$$

Therefore, the dimensionless load carrying capacity for globular sphere model is expressed as

$$
\begin{gathered}
W=3\left(1+\frac{5}{2} \phi\right)(1+\tau) \int_{1}^{k} \frac{R^{3}}{g(\bar{h})+A} d R- \\
-3\left(1+\frac{5}{2} \phi\right)(1+\tau) \frac{\left[\int_{1}^{k} \frac{R d R}{g(\bar{h})+A}\right]^{2}}{\int_{1}^{k} \frac{d R}{R\{g(\bar{h})+A\}}}
\end{gathered}
$$

\subsection{A capillary fissures model as shown in Figure 3}

This model of porous sheets consists of three sets of mutually orthogonal fissures with a mean solid size 


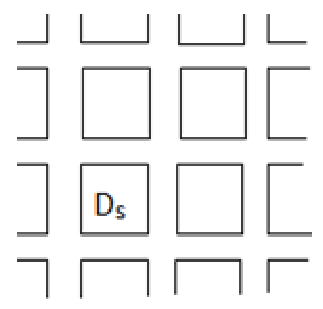

Figure 3. Geometry of capillary fissures model.

[29] derived the following expression for the permeability of the grid of cubes considering no loss of hydraulic gradient at the junctions, valid for $\mathrm{e} \ll 1$;

$$
\psi=\frac{D_{s}^{2}\left(1-m^{\frac{1}{3}}\right)^{3}\left(1+m^{\frac{1}{3}}\right)}{I^{*}(1-e)}
$$

where $m=1-e$ and $\mathrm{I}^{*}$ is a parameter known to depend on the morphology of pores.

Resorting to the non dimensional quantities (16) and the boundary conditions (17), the expression for non dimensional pressure distribution for Irmay's model takes the form:

$$
\begin{gathered}
P=-6\left(1+\frac{5}{2} \phi\right)(1+\tau) \int_{1}^{R} \frac{R}{g(\bar{h})+D} d R+ \\
+C_{2} \int_{1}^{R} \frac{d R}{R\{g(\bar{h})+D\}}
\end{gathered}
$$

where

$$
C_{2}=6\left(1+\frac{5}{2} \phi\right)(1+\tau) \frac{\int_{1}^{k} \frac{R d R}{g(\bar{h})+D}}{\int_{1}^{k} \frac{d R}{R\{g(\bar{h})+D\}}}
$$

By making use of (19), the expression for the dimensionless form of load carrying capacity is calculated as

$$
\begin{gathered}
W=3\left(1+\frac{5}{2} \phi\right)(1+\tau) \int_{1}^{k} \frac{R^{3}}{g(\bar{h})+D} d R- \\
--3\left(1+\frac{5}{2} \phi\right)(1+\tau) \frac{\left[\int_{1}^{k} \frac{R d R}{g(\bar{h})+D}\right]^{2}}{\int_{1}^{k} \frac{d R}{R\{g(\bar{h})+D\}}}
\end{gathered}
$$

\section{RESULTS AND DISCUSSION}

It is easily observed that the dimensionless pressure distribution in the bearing system given by equation (18) and equation (21) while the non dimensional load carrying capacity of the bearing system is obtained from equation (20) and equation (22). It is clearly seen that the pressure increases by

$$
\left(6\left(1+\frac{5}{2} \phi\right) \tau\right) \int_{R}^{1} \frac{R}{g(\bar{h})+A} d R
$$

and

$$
\left(6\left(1+\frac{5}{2} \phi\right) \tau\right) \int_{R}^{1} \frac{R}{g(\bar{h})+D} d R
$$

respectively while the increase in load carrying capacity turns out to be

$$
\left(3\left(1+\frac{5}{2} \phi\right) \tau\right) \int_{1}^{k} \frac{R^{3}}{g(\bar{h})+A} d R
$$

and

$$
\left(3\left(1+\frac{5}{2} \phi\right) \tau\right) \int_{1}^{k} \frac{R^{3}}{g(\bar{h})+D} d R
$$

respectively, in comparison with the conventional lubricants.

Moreover, it is transparent from equation (20) and equation (22) that the expression is linear with respect to the magnetization parameter $\tau$. As a result increasing value of the magnetization parameter would lead to increased load carrying capacity. It is not surprising because the magnetization increases the effective viscosity of the lubricant there by increasing the pressure and consequently the load carrying capacity. Setting the magnetization parameter to be zero for a porous bearing with smooth surfaces the current investigation reduces to the discussion of [30]. In particular, the current investigation also includes the study of [31]. In the absence of porosity this study reduces to the investigation of [1] for a bearing with smooth surfaces when lower plate's curvature parameter is zero.

The graphical representations concerning the Kozeny-Carman model and Irmay's model are presented in Figures 4-33.

Here the morphology parameter significantly contributes towards the enhancement of the load carrying capacity which can be seen from Figures 4-8 for Kozeny-Carman model and 9-13 for Irmay's model. However, the rate of increase in the load carrying capacity due to morphology parameter gets decreased with large value of lower plate's curvature parameter for Kozeny-Carman model.

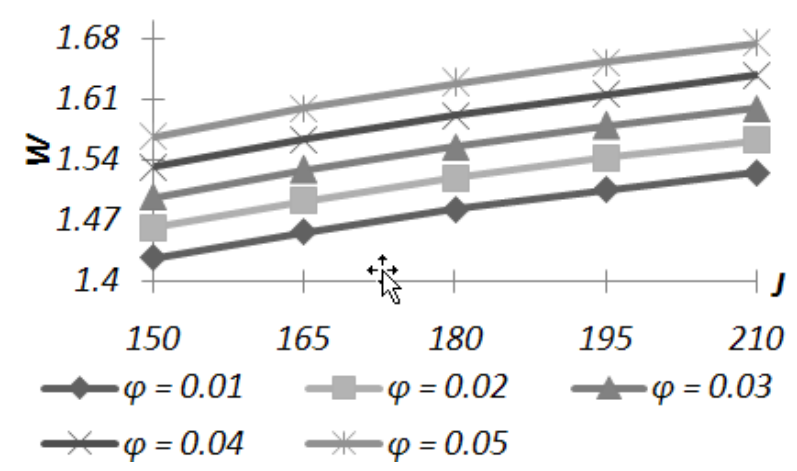

Figure 4. Variation of Load carrying capacity with respect to $J$ and $\varphi$. 


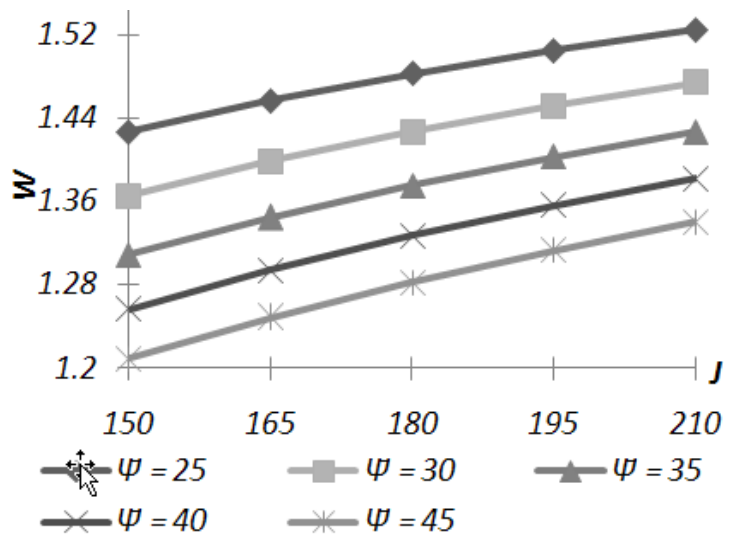

Figure 5 . Variation of Load carrying capacity with respect to $\mathrm{J}$ and $\Psi$

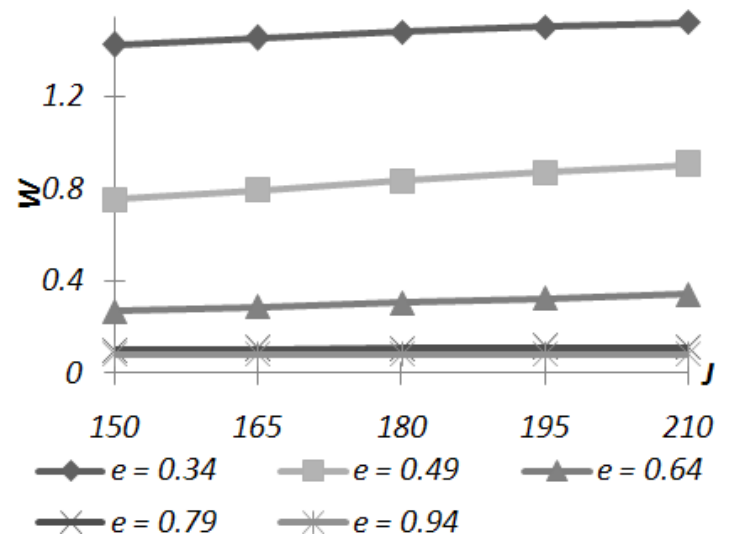

Figure 6. Variation of Load carrying capacity with respect to $\mathrm{J}$ and $\mathrm{e}$.

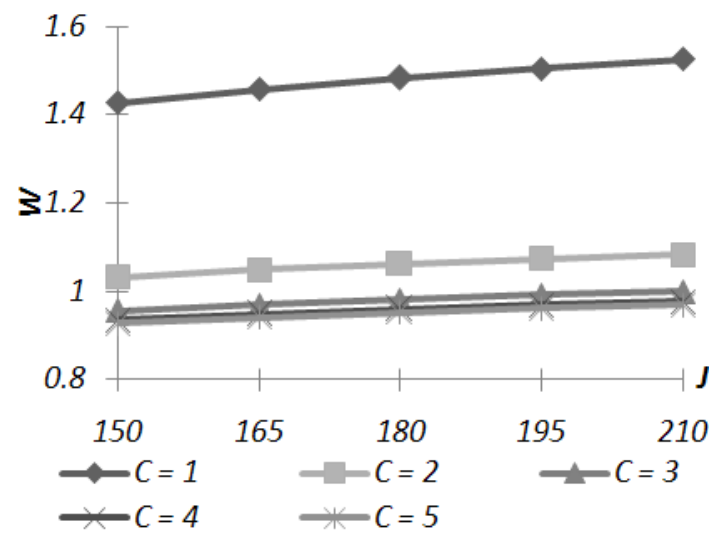

Figure 7. Variation of Load carrying capacity with respect to $\mathrm{J}$ and $\mathrm{C}$.

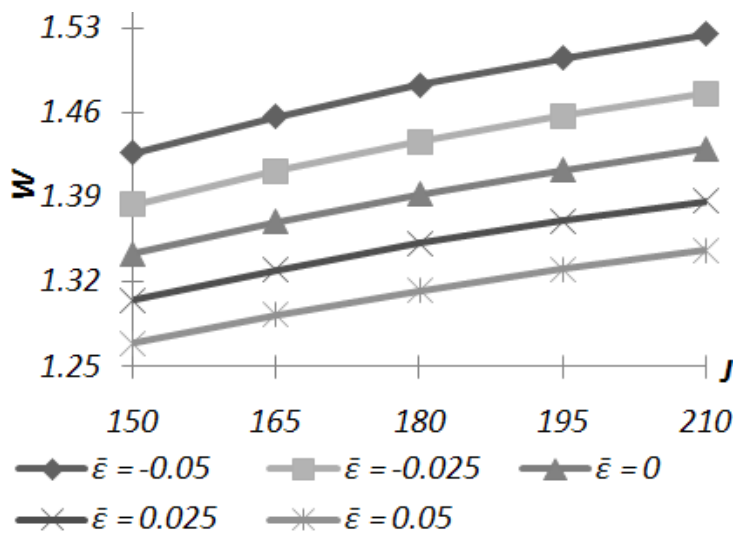

Figure 8. Variation of Load carrying capacity with respect to $\mathrm{J}$ and $\bar{\varepsilon}$

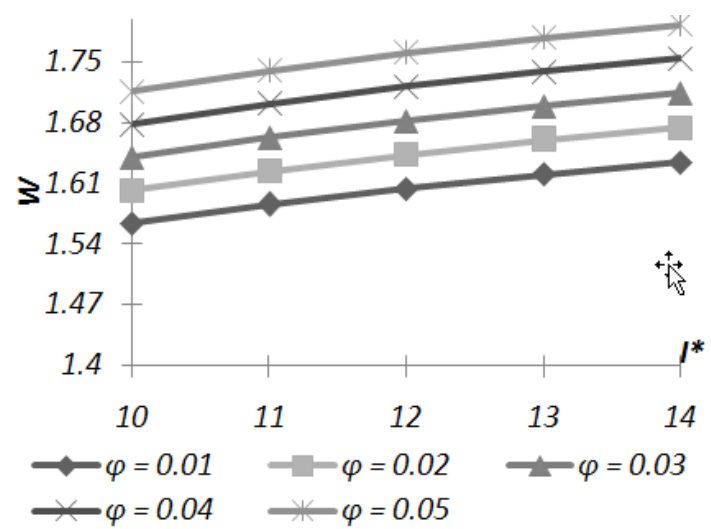

Figure 9. Variation of Load carrying capacity with respect to I* and $\varphi$.

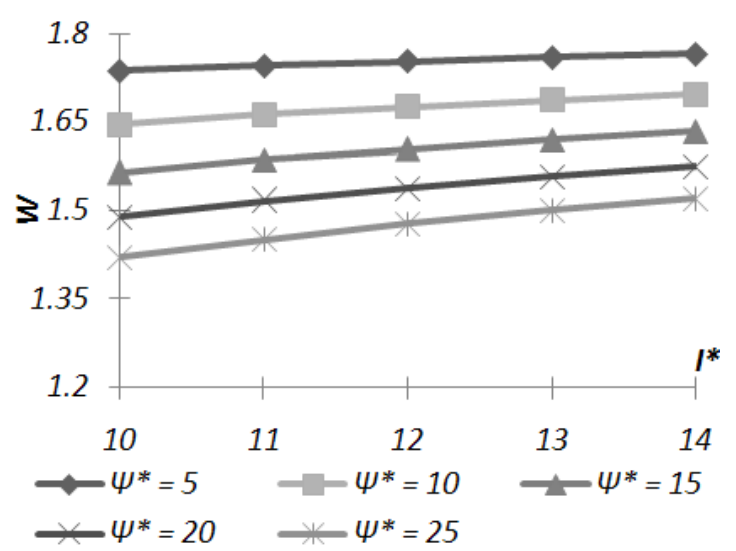

Figure 10. Variation of Load carrying capacity with respect to $I^{*}$ and $\Psi^{*}$

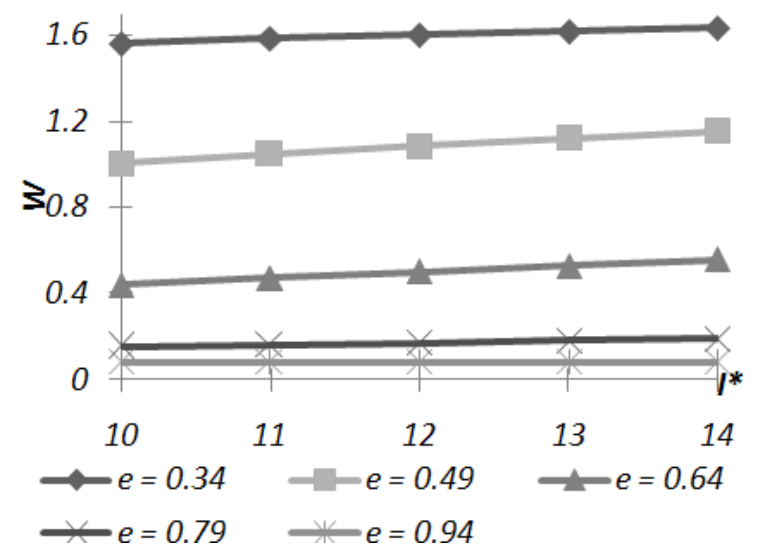

Figure 11. Variation of Load carrying capacity with respect to $I^{*}$ and $e$.

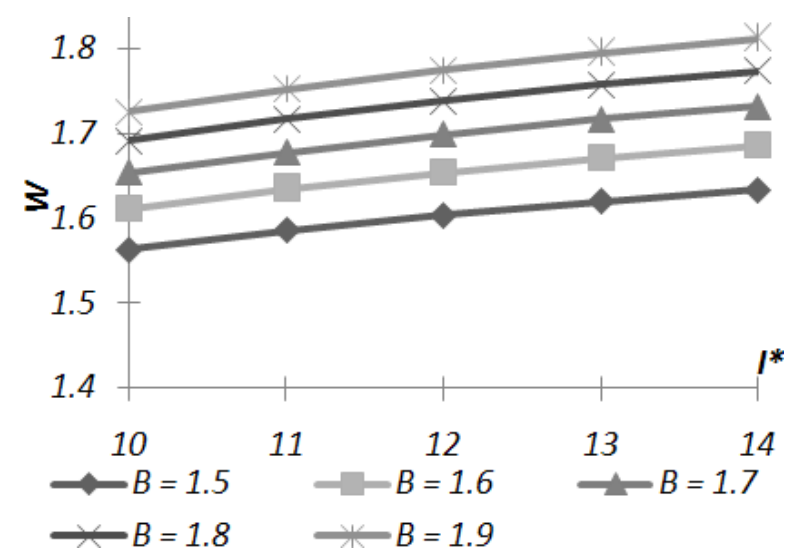

Figure 12. Variation of Load carrying capacity with respect to $\mathrm{I}^{*}$ and $\mathrm{B}$. 


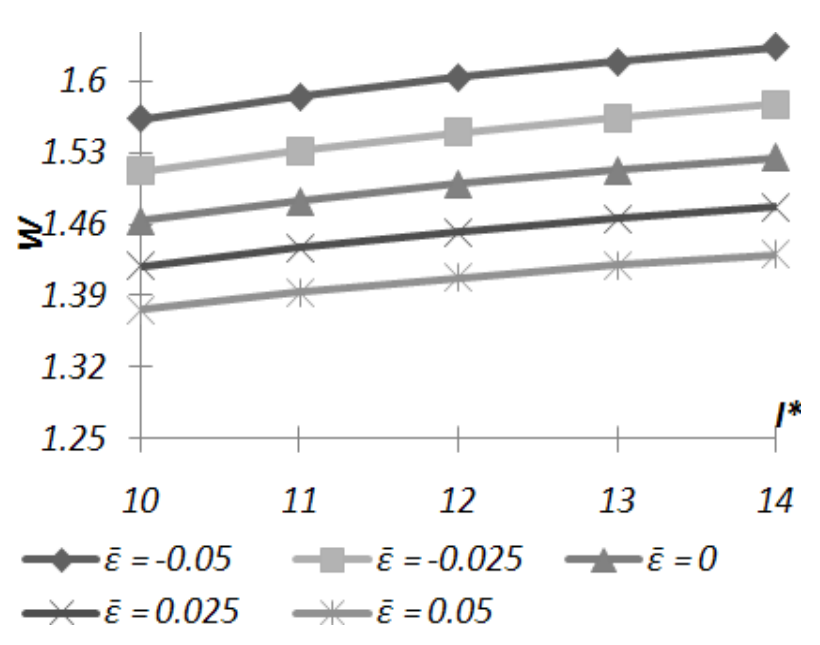

Figure 13. Variation of Load carrying capacity with respect to $\mathrm{I}^{\wedge *}$ and $\bar{\varepsilon}$

Further, by increasing the volume concentration parameter load carrying capacity can be increased which is exhibited in Figures 14-17 for KozenyCarman's formulation and 18-21 for Irmay's model. Moreover, this rate of increase in the load carrying capacity due to volume concentration parameter stabilizes for higher values of porosity parameter and lower plate's curvature parameter

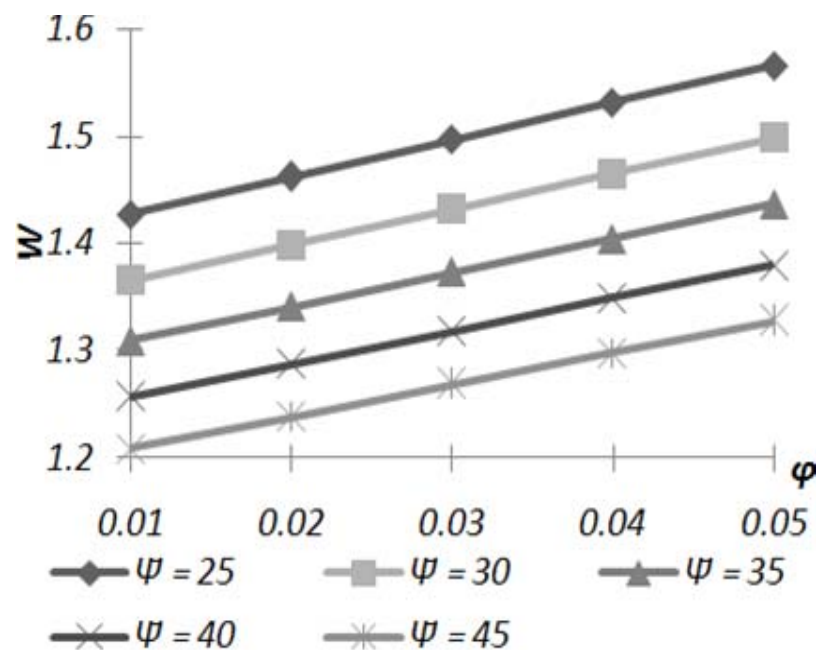

Figure 14. Variation of Load carrying capacity with respect to $\varphi$ and $\bar{\Psi}$

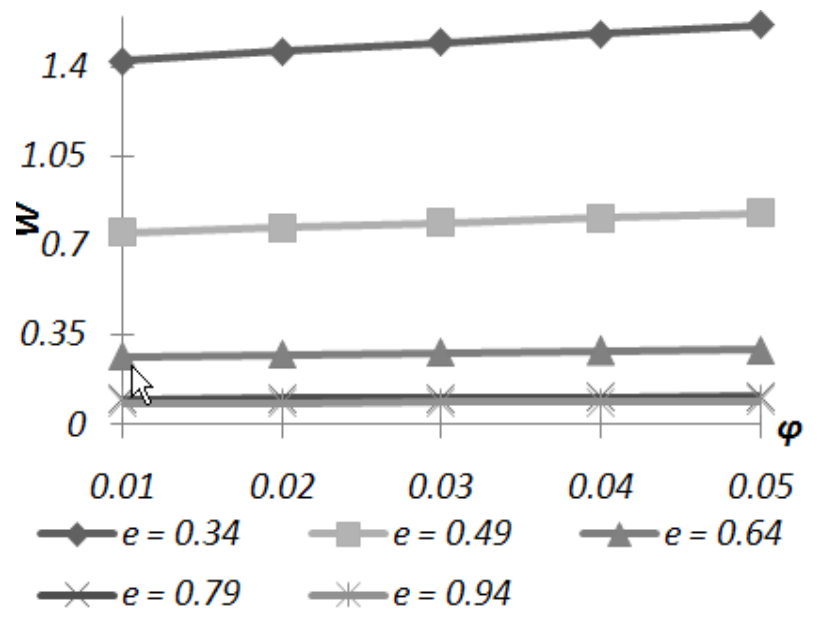

Figure 15. Variation of Load carrying capacity with respect to $\varphi$ and $e$

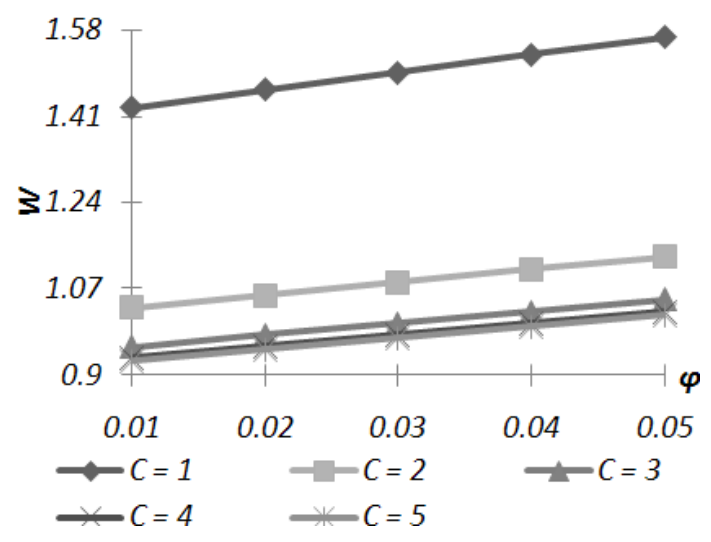

Figure 16. Variation of Load carrying capacity with respect to $\varphi$ and $C$

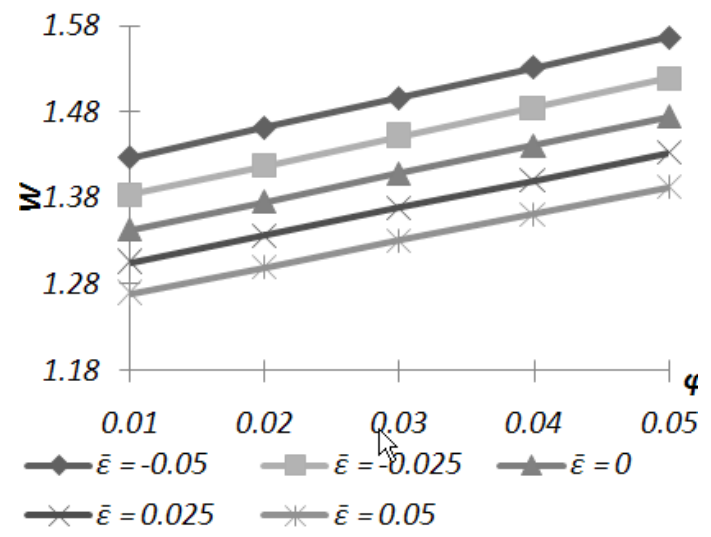

Figure 17. Variation of Load carrying capacity with respect to $\phi$ and $\bar{\varepsilon}$

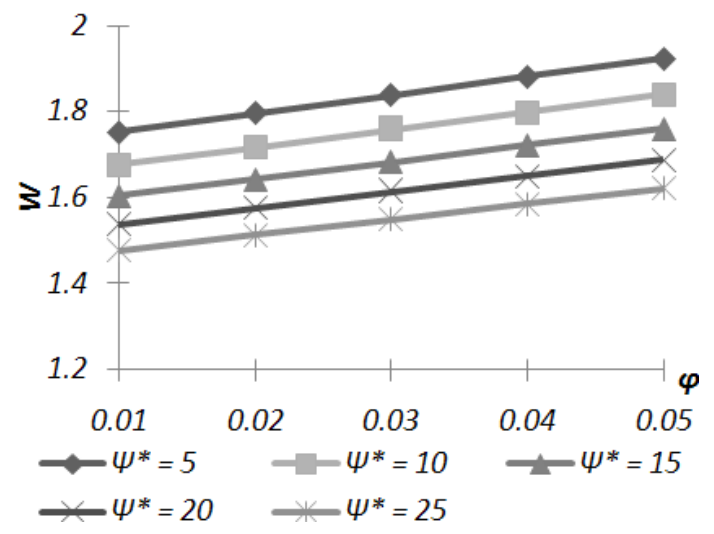

Figure 18. Variation of Load carrying capacity with respect to $\Phi$ and $\Psi^{*}$

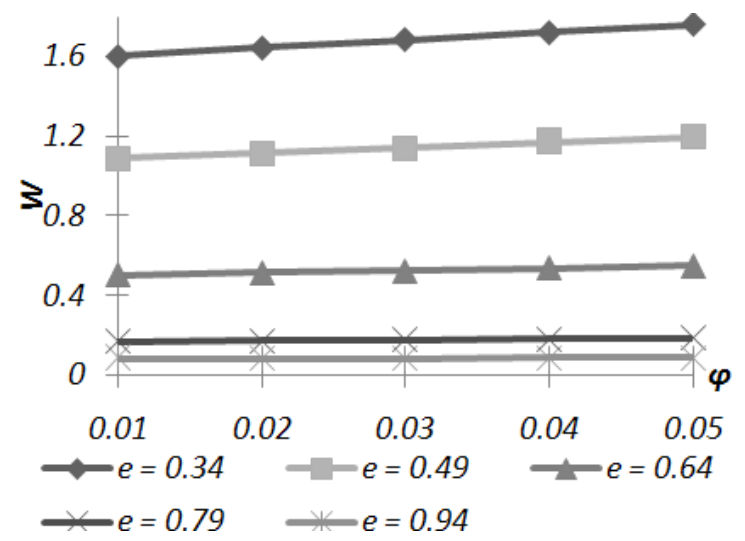

Figure 19. Variation of Load carrying capacity with respect to $\varphi$ and $e$. 


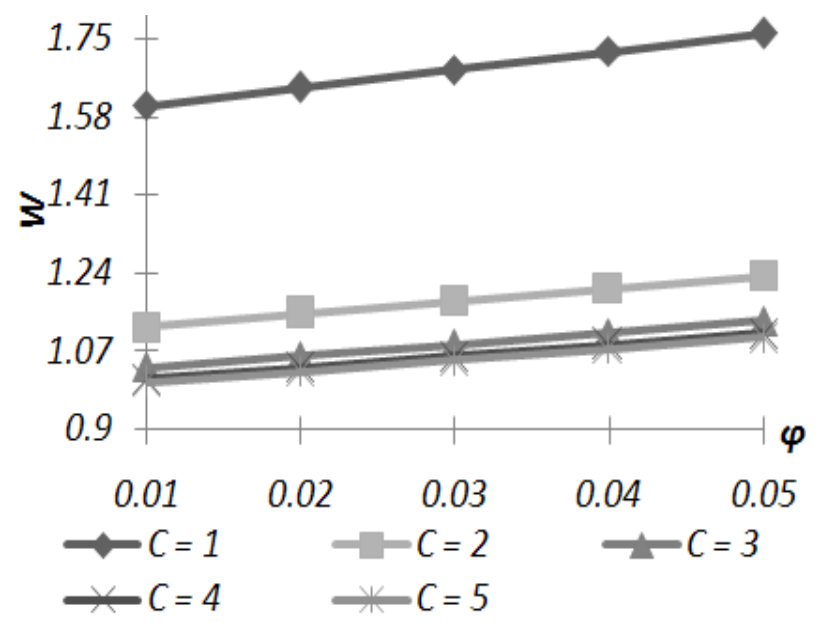

Figure 20. Variation of Load carrying capacity with respect to $\varphi$ and $C$.

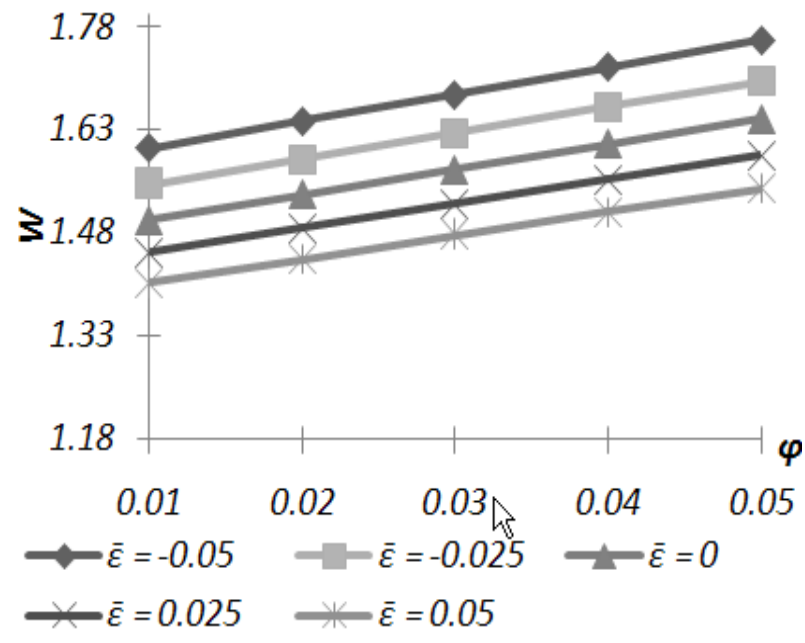

Figure 21. Variation of Load carrying capacity with respect to $\varphi$ and $\bar{\varepsilon}$

The porous structure has relatively more effect in the case of Irmay's model which can be encountered in Figures 22-24 for Kozeny-Carman's model and 25-27 for Irmay's model. But, the rate of decrease in the load carrying capacity due to porous structure parameter gets decreased with large value of porosity parameter and lower plate's curvature parameter.

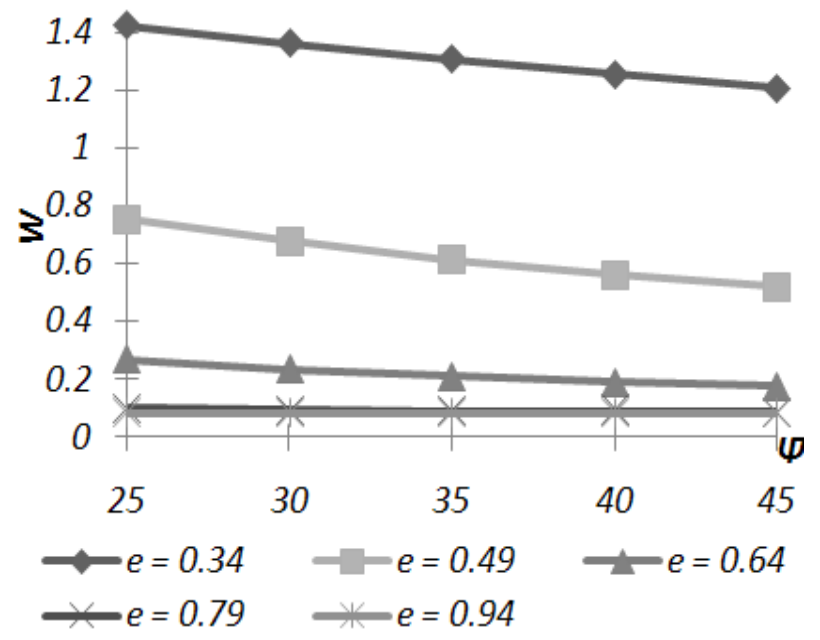

Figure 22. Variation of Load carrying capacity with respect to $\Psi^{-}$and $e$.

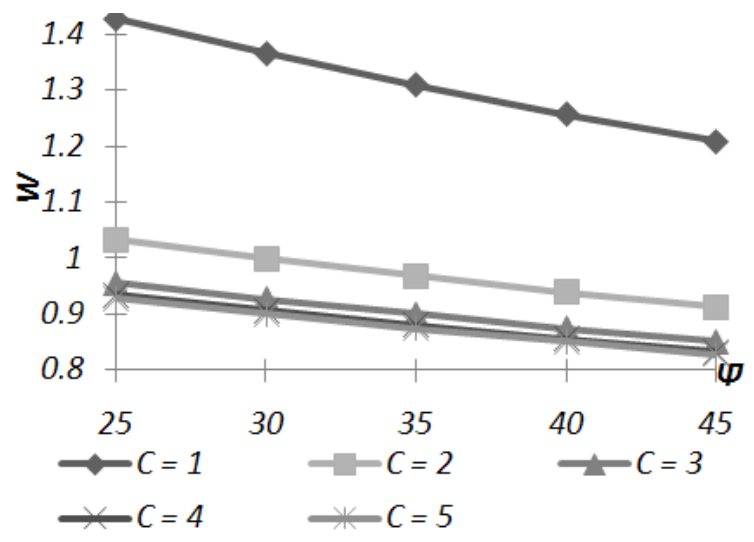

Figure 23. Variation of Load carrying capacity with respect to $\Psi^{-}$and $\mathrm{C}$.

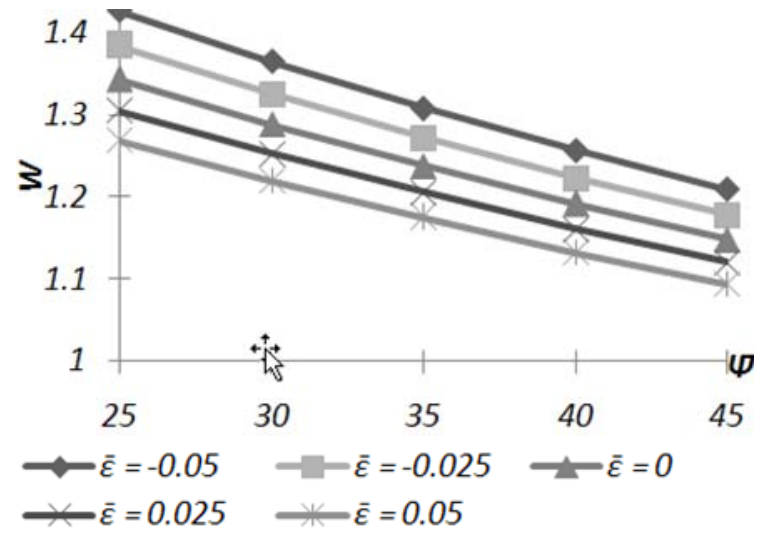

Figure 24. Variation of Load carrying capacity with respect to $\Psi^{-}$and $\bar{\varepsilon}$.

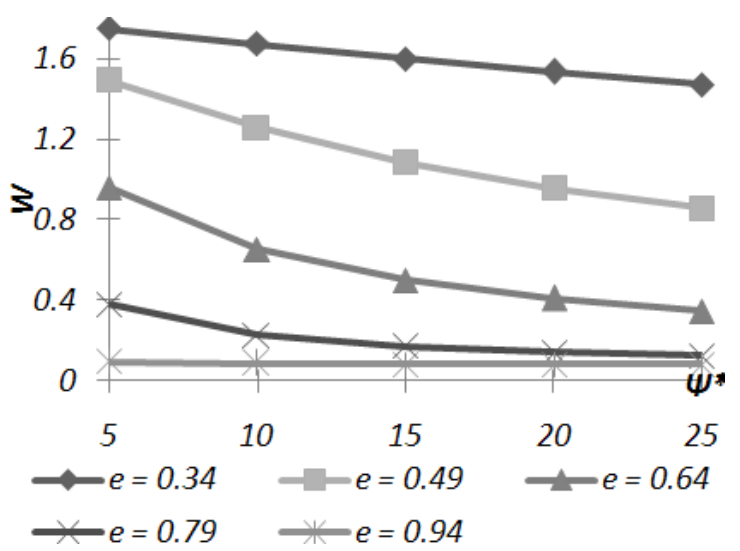

Figure 25. Variation of Load carrying capacity with respect to $\Psi^{\wedge *}$ and e.

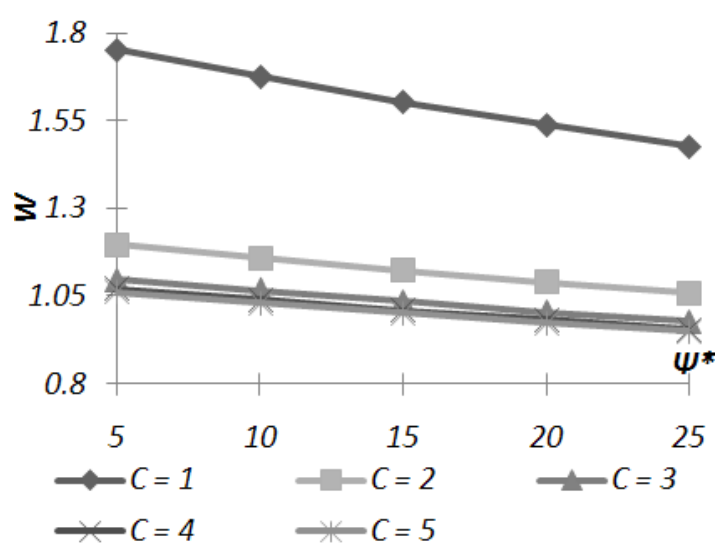

Figure 26. Variation of Load carrying capacity with respect to $\Psi^{\wedge *}$ and C. 


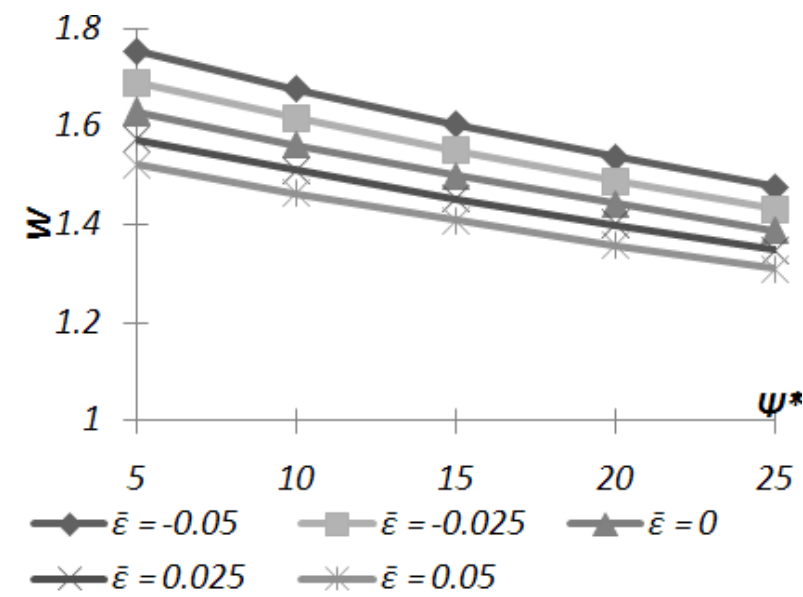

Figure 27. Variation of Load carrying capacity with respect to $\psi^{*}$ and $\bar{\varepsilon}$

[32] suggested that for porosity in between 0.25 and 0.65 the Kozeny- Carman's formulation and Irmay's model agree reasonably well in the sense that the performance differed by at the best 8 to $9 \%$. This is visible from the Figures presented below.

By increasing the upper plate's curvature parameter and lowering the lower plat's curvature parameter the bearing performance characteristics may be enhanced for both the models as can be witnessed from Figures 28 for Kozeny-Carman's formulation and 29 for Irmay's model.

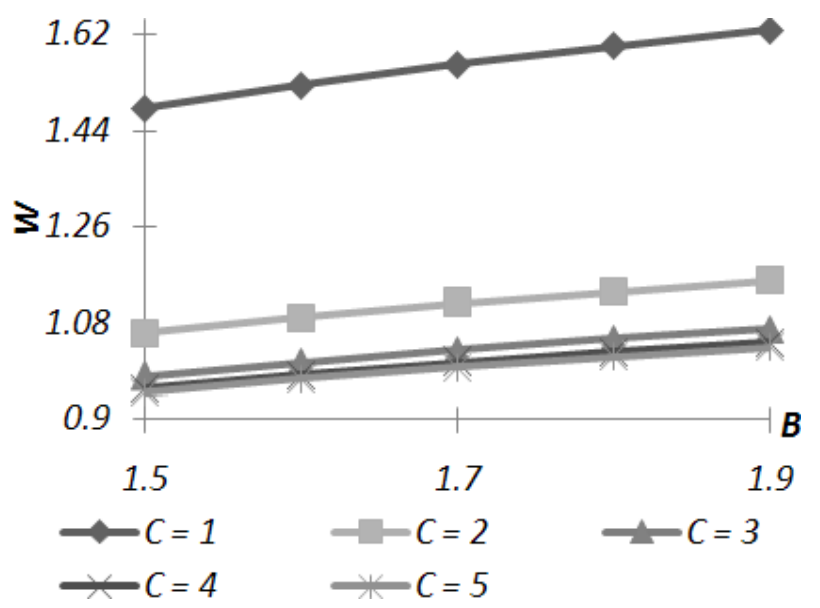

Figure 28: Variation of Load carrying capacity with respect to $B$ and $C$.

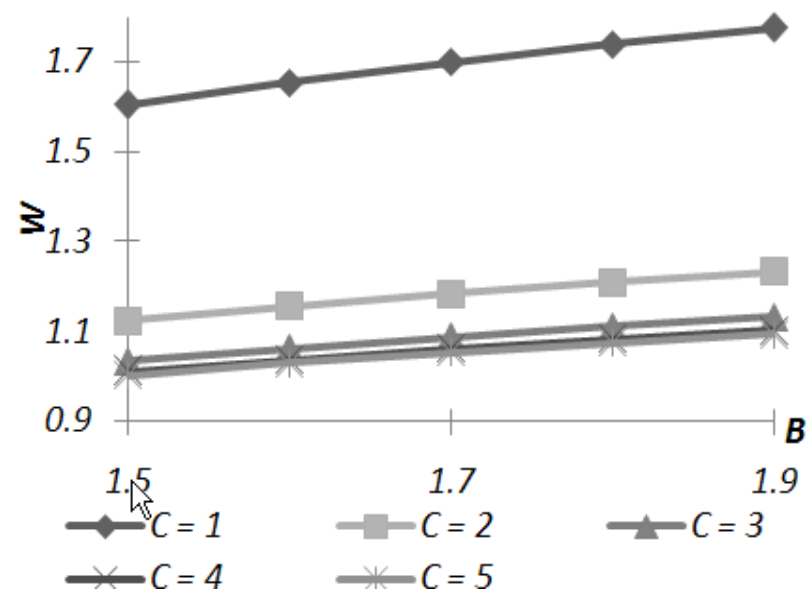

Figure 29: Variation of Load carrying capacity with respect to $B$ and $C$
The effect of roughness is provided in Figures 30-31 for Kozeny-Carman model and 32-33 for Irmay's model. It is easily observed from Figure 30 that the combined effect of standard deviation and positive skewness is considerably adverse in the sense that it results in heavy decrease in load carrying capacity.

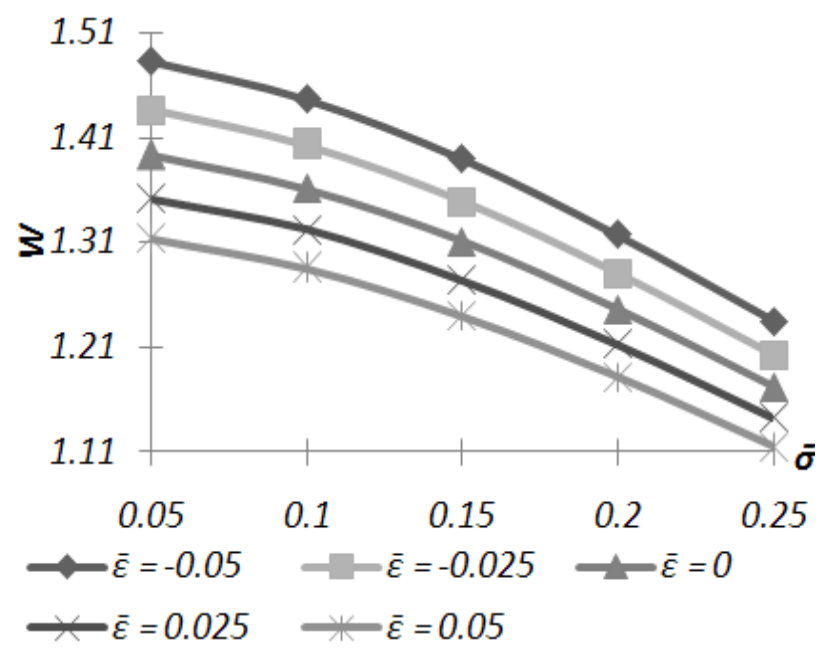

Figure 30: Variation of Load carrying capacity with respect to $\bar{\sigma}$ and $\bar{\varepsilon}$

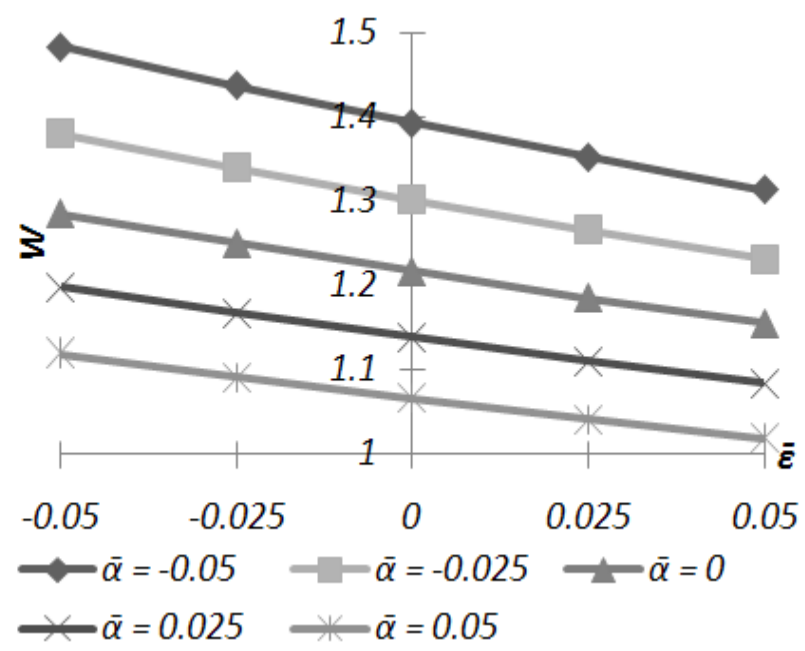

Figure 31: Variation of Load carrying capacity with respect to $\bar{\varepsilon}$ and $\bar{\alpha}$

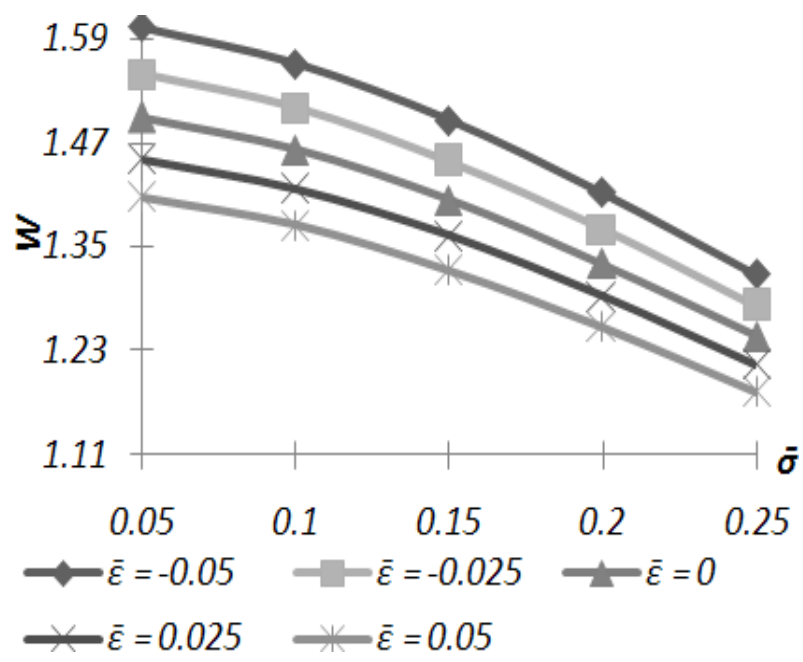

Figure 32: Variation of Load carrying capacity with respect to $\bar{\sigma}$ and $\bar{\varepsilon}$ 


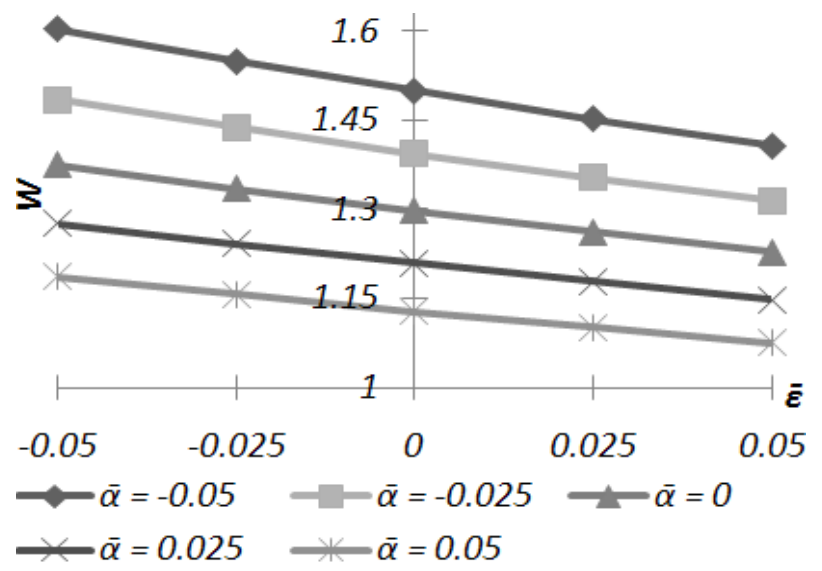

Figure 33: Variation of Load carrying capacity with respect to $\bar{\varepsilon}$ and $\bar{\alpha}$

From the above graphical representations, it is clear that the increase in standard deviation results in decreased load carrying capacity. However, the load carrying capacity gets increased due to negatively skewed roughness but positive skewness introduces a decrease in load carrying capacity. The trends of the variance appear quite similar to that of skewness. The decrease in the load carrying capacity is basically due to the fact that transverse roughness retards the motion of the lubricant.

Some of the graphs presented here reveal the following: 1. The morphology parameter and the volume concentration parameter significantly increase the load carrying capacity.

2. Further, it is observed that at least in the case of negatively skewed roughness the adverse effect of porosity and standard deviation can be compensated to a large extent. This compensation being more in the case of Irmay's model.

3. Although, the trends are similar for both the models the load carrying capacity is found to be more in the case of Irmay's model.

4. The combine effect of porosity and the porous structure is relatively more for the case of Irmay's model.

5. As suggested by the Figures the negatively variance induced increase in load carrying capacity gets further increased owing to negatively skewed roughness which may mitigate the negative effect of porosity to some extent.

6. It is noticed that the bearing system can support certain amount of load even in the absence of flow which does not happen in the case of conventional lubricants.

7. A constant magnetic field fails to significantly enhance the performance characteristics in the Neuringer-Rosensweig model but it does so in the Shliomis model where in the rotation of magnetic particles and their moments are taken into consideration. Here also Irmay's model scores over the KozenyCarman model, so far as Shliomis model based ferrofluid lubrication is concerned.

\section{CONCLUSION}

Although the effect of transverse roughness is adverse in general, this investigation offers the suggestion that the bearing performance can be improved significantly by the positive effect of magnetization at least in the case of negatively skewed roughness for Irmay's model. Further, this article establishes that the roughness must be given due consideration while designing the bearing system even when Irmay's model is in place. Needless to say is that Irmay's model may be preferred over the Kozeny-Carman's model for an overall improved performance.

\section{ACKNOWLEDGMENT}

The authors acknowledge with thanks the fruitful comments and suggestions of the reviewers and the editor.

\section{REFERENCES}

[1] Shah, R.C. and Bhat, M.V.: Ferrofluid squeeze film between curved annular plates including rotation of magnetic particles, Journal of Engineering Mathematics, Vol. 51, pp. 317-324, 2005.

[2] Shimpi, M.E. and Deheri, G.M.: A study on the performance of magnetic fluid based squeeze film in curved porous rotating rough annular plates and deformation effect, Tribology International, Vol. 47, pp. 90-99, 2012.

[3] Basti, D.P.: Effect of surface roughness and couple stresses on squeeze films between curved annular plates, ISRN Tribology, Vol. 2013, Article ID 640178, 2013.

[4] Shliomis, M.I.: Effective viscosity of magnetic suspensions, Sov. Physics JETP, Vol. 34, pp. 12911294, 1972.

[5] Gupta, J.L., Vora, K.H. and Bhat, M.V.: The effect of rotational inertia on the squeeze film load between porous annular curved plates, Wear, Vol. 79, No. 2, pp. 235-240, 1982.

[6] Bacri, J.C., Perzynski, R., Shliomis, M.I. and Burde, G.I.: "Negative- viscosity" effect in a magnetic fluid, Physical review letters, Vol. 75, No. 11, pp. 2128-2131, 1995.

[7] Lu, R.F., Chien, R.D. and Lin, J.R.: Effects of fluid inertia in magneto-hydrodynamic annular squeeze films, Tribology International, Vol. 39, No. 3, pp. 221-226, 2006.

[8] Singh, U.P. and Gupta, R.S.: Dynamic performance characteristics of a curved slider bearing operating with ferrofluid, Advances in Tribology, Vol. 2012, Article Id 278723, 2012.

[9] Lin, J.R.: Fluid inertia effects in ferrofluid squeeze film between a sphere and a plate, Applied Mathematical Modelling, Vol. 37, pp. 5528-5535, 2013.

[10] Liu, J.: Analysis of a porous elastic sheet damper with a magnetic fluid, Journal of Tribology, Vol. 131, pp. 0218011-15, 2009.

[11] Shah, R.C. and Patel, D.B.: Squeeze Film Based on Ferrofluid in Curved Porous Circular Plates with Various Porous Structures, Applied Mathematics, Vol. 2, No. 4, pp.121-123, 2012. 
[12] Patel, J.R. and Deheri, G.M.: Shliomis Model Based Ferrofluid Lubrication of Squeeze Film in Rotating Rough Curved Circular Disks with Assorted Porous Structures, American Journal of Industrial Engineering, Vol. 1, No. 3, pp. 51-61, 2013.

[13] Tzeng, S.T. and Saibel, E.: Surface roughness effect on slider bearing lubrication, ASME Trans. J. Lub. Tech., Vol. 10, pp. 334-338, 1967.

[14] Christensen, H. and Tonder, K.C.: Tribology of rough surfaces: stochastic models of hydrodynamic lubrication, SINTEF, Report No.10/69-18, 1969a.

[15] Christensen, H. and Tonder, K.C.: Tribology of rough surfaces: parametric study and comparison of lubrication models, SINTEF, Report No.22/ 69-18, $1969 b$.

[16] Christensen, H. and Tonder, K.C.: The hydrodynamic lubrication of rough bearing surfaces of finite width, ASME-ASLE Lubrication Conference, Cincinnati. OH. Paper no. 70-lub-7, October 12-15, 1970

[17] Prajapati, B. L.: Behaviour of squeeze film behaviour between rotating porous circular plate: surface roughness and elastic deformation effects, J. Pure Appl. Math. Sci., Vol. 33, No. 1-2, pp. 2736, 1991.

[18] Gupta, J.L. and Deheri, G.M.: Effect of roughness on the behavior of squeeze film in a spherical bearing, Tribol. Trans., Vol. 39, pp. 99-102, 1996.

[19]Lin, J.R., Lu, R.F., Liao, W.H.: Analysis of magneto-hydrodynamic squeeze film charecteristics between curved annular plates, Industrial Lubrication and Tribology, vol. 56, No. 5, pp. $300-$ $305,2004$.

[20] Vadher, P.A., Vinodchandra, P.C., Deheri, G.M., Patel, R.M.: A Study of the behaviour of hydromagnetic squeeze film between two conducting rough porous annular plates, Proc. Pakistan Acad. Sci., Vol. 45, No. 2, pp. 81-95, 2008.

[21] Patel R.M., Deheri G.M., Vadher P.A.: Magnetic fluid based squeeze film between annular plates and transverse surface roughness effects, Annals of Faculty Engineering Hunedoara-International Journal of Engineering, Tome VIII. Fascicule 1, pp. 51-56, 2010.

[22] Deheri, G.M., Patel, R.M., and Abhangi, N. D.: Magnetic fluid-based squeeze film behavior between transversely rough curved annular plates: a comparative study, Industrial Lubrication and Tribology, Vol. 63, No. 4, pp.254 - 270, 2011.

[23] Patel, N.D. and Deheri, G.M.: Effect of rotation of magnetic particles on a ferrofluid squeeze film between porous curved annular plates and surface roughness effect, Journal of Mechanical and Industrial Engineering Research, Vol. 2, No.2, pp. 17-33, 2013.

[24] Patel, J.R. and Deheri, G.M.: Shliomis model based magnetic fluid lubrication of a squeeze film in rotating rough curved circular plates, Caribbean
Journal of Science and Technology, Vol.1, pp.138150, 2013.

[25]Bhat, M.V.: Lubrication with a Magnetic fluid, Team Spirit (India) Pvt. Ltd., Ahmedabad, India, 2003.

[26] Prajapati, B.L.: On Certain Theoretical Studies in Hydrodynamic and Electro-magneto hydrodynamic Lubrication, PhD Thesis: S.P. University, Vallabh Vidyanagar, Gujarat, India.

[27]Deheri, G.M., Andharia, P.I. and Patel, R.M.: Transversely rough slider bearings with squeeze film formed by a magnetic fluid, Int. J. of Applied Mechanics and Engineering, Vol. 10, No. 1, pp. 5376, 2005.

[28] Patel, J.R. and Deheri, G.M.: A comparison of porous structures on the performance of a magnetic fluid based rough short bearing, Tribology in Industry, Vol. 35, No. 3, pp. 177-189, 2013.

[29] Irmay, S.: Flow of liquid through cracked media, Bull. Res. Counc. Isr, Vol. 5A, No.1/84, 1955.

[30] Prakash, J. and Vij, S.K.: Load capacity and time height relation between porous plates, Wear, Vol. 24, pp. 309-322, 1973.

[31] Gupta, J.L. and Vora, K.H.: Analysis of the squeeze film between curved annular plates, ASME J. Lubr. Technol., Vol. 102, pp. 48-50, 1980.

[32] Bear, J., Zaslavsky, D. and Irmay S.: Physical Principles of Water Percolation and Seepage, Unesco, 1968.

\section{ТЕОРИЈСКО ПРОУЧАВАЊЕ ШЛИОМИСОВОГ МОДЕЛА ЗАСНОВАНОГ НА МАГНЕТНОМ ФЛУИДУ БАЗИРАНОМ НА СТИСНУТОМ ФИЛМУ КОД ХРАПАВИХ ЗАКРИВЉЕНИХ ПРСТЕНАСТИХ ПЛОЧА СА ОДАБРАНОМ ПОРОЗНОМ СТРУКТУРОМ}

\section{Jimit R. Patel, Gunamani Deheri}

У овом теоријском истраживању разматра се утицај Шлиомисовог модела, базираног на подмазивању гвозденим флуидом, на стиснути филм између закривљених храпавих прстенастих плоча поређењем са две различите порозне структуре. КозениКарманова формулација и Ирмејев модел су усвојени за порозне структуре. Стохастички модели Кристенсена и Тондера се користе за карактеризацију попречне храпавости. Једначина Рејнолдсовог типа се решава да би се добила дистрибуција притиска, што доводи до израчунавања носивости. Графички приказ показује да се неповољан утицај попречне храпавости може минимизовати позитивним ефектом магнетизације у случају негативно укрштене храпавости избором одговарајућих параметара кривине. Даље, изгледа да је ова компензација већа у случају Ирмејевог модела у поређењу са КозениКармановом методом, што Ирмејев метод чини погоднијим за усвајање. Утврђено је да ефекат параметра морфологије и параметра концентрације запремине повећава носивост система лежајева. 